\title{
Beech Forest Vegetation Database of SE Balkan
}

\author{
Aleksander Marinšek
}

\begin{abstract}
Beech forest vegetation database of SE Balkan Peninsula (GIVD ID EU-00-012) held at Institute of Biology SRC SASA, Ljubljana, Slovenia. It contains published relevé material from the territory of Slovenia, Croatia, Bosnia and Herzegovina, Serbia, Macedonia, Montenegro, Bulgaria and Greece. Relevés originate mainly from published sources and also from grey literature (theses, survey reports, manuscripts, etc.). The database is used for archiving relevé material, for preparation of classifications and other analyses of beech forest vegetation of Balkan Peninsula.
\end{abstract}

Keywords: Fagus sylvatica; relevé.

\section{Beech Forest Vegetation Database of SE Balkan}

Scope: The database comprises vegetation relevés of beech forests from Slovenia, Croatia, Bosnia and Herzegovina, Serbia, Montenegro, Bulgaria, Macedonia and Northern Greece.

Status: completed and continuing Period: $1938-2010$

Database manager(s): Aleksander Marinšek (marinsek@zrc-sazu.si)

Owner: [NA]

Web address: [NA]

Availability: after blocking period

Database format(s): TURBOVEG

Online upload: [NA]

Online search: [NA]

Publication: [NA]

Plot type(s): normal plots

Export format(s): TURBOVEG, Excel

Non-overlapping plots: 5,952

Total plot observations: 5,952

Plot-size range: $16-6,400 \mathrm{~m}^{2}$

Countries: BA: 11.8\%; BG: $8.2 \%$; GR: $8.0 \%$; HR: 12.9\%; ME: 0.5\%; MK: $2.9 \%$; RS: $11.6 \%$; SI: $44.1 \%$

Forest: [NA] — Non-forest: [NA]

Guilds: all vascular plants: $100 \%$; bryophytes (terricolous or aquatic): $35 \%$

Environmental data: altitude: $98 \%$; slope aspect: $96 \%$; slope inclination: $86 \%$

Performance measure(s): cover: $100 \%$

Geographic localisation: [NA]

Sampling periods: [NA]

Information as of 2012-07-12; further details and future updates available from http://www.givd.info/ID/EU-00-012

Aleksander Marinšek (marinsek@zrc-sazu.si)

Scientific Research Centre of the Slovenian Academy of Sciences and Arts, Institute of Biology, Novi trg 2, 1000 Ljubljana, SLOVENIA 